\title{
Entity and Nationality in the Fictional Narratives of Amitav Ghosh
}

\author{
Md. Eftekhar Uddin \\ Department of English language \& Literature, International Islamic University Chittagong \\ 154/A College Road, Chittagong- 4203, Bangladesh
}

\begin{abstract}
There has been a lot of interest, even admiration, for the fiction written in and about India in the last two decades. Writers like Salman Rushdie, Amitav Ghosh and Arundhati Roy have given a 'magical' turn to these writings, thus, engendering a transformation much beyond the conventional terms of description. Coming after the fictional writers of anti-colonial struggles and nationalist movement, the current crop of fiction writers seem to respond to the shift towards discourse, identities and communities (Bose \& Jalal 8) which broadly underpin the efforts of writing about the postcolonial societies. Ghosh, with an awareness of such a shift, creates a body of fiction, which, while enlarging the forms of writing histories, tries to describe the political and social manifestations of postcolonial India. In fact, Ghosh's fiction can be said to betray a deep understanding of the process of de-colonization with evocative descriptions of the community and the post-national identity. Subversive descriptions of colonial certitudes and rigidities of the nation-state inform this understanding. The setting and the narrative contents of the fiction signify overlapping experiences and intertwined histories of South Asia, brought out by a single colonial rule. This study focuses on these aspects and the affected structural changes in the fictional narratives of Ghosh. A broad look at the evolution of the novel form in India and the problem of nationalism make a context for this study.
\end{abstract}

Keywords: Indian Fiction, Memory as a Narrative device, Nationality.

\section{Introduction}

Indian English fiction, an obvious 'cultural consequence' of the colonial rule, can trace its origins only to thirteenth century. Drawing on the available native traditions of kathas, upakathas and other 'fairy story like narratives surviving in the public memory' (Nandy 18), it quickly gained (Nandy 17) legitimacy and started growing into 'the interstices of the Indian literary world'. Accounting for the popularity and acceptance of the form Ashis Nandy writes:

After all the reason for the popularity of the novel form in South Asia was its ability to take up issues and themes that were peripheral to traditional forms of literature. For instance, the novel could be used, India writers found out, for political, polemical and satirical purposes. (18)

While Nandy elaborates this insight with the now famous examples of Bankimchandra and Rabindranath Tagore, what is important is that the novel, both in regional literatures and in Indian English literature, combines the narrative traditions of South Asia 'an abacus of storytelling' to use Ghosh's own phrase, with the political and cultural conditions of colonialism and its aftermath. This peculiar ability makes it transcend or grow out of its colonial origins and relate to the contemporary social reality more than any other literary form.

\section{Fiction In India}

Fiction writers of the generation of R. K. Narayan and Mulk Raj Anand, coming after the orientalist writings and other tentative attempts of transitional nature, could only allow their fictional narratives to be captivated by the ideologies of nationalism and the engaging immediacy of the politics of anti-imperialism. Much of their fiction provides variations of these and other allied themes. These writers and their writings, having seen their course run through relevant themes and concerns, have begun to create space for a generation of the writers of the midnight's children who write with markedly new concerns and nuances.

The new space for these writers emerged after the two factors, among others, which tremendously influenced the earlier writers began to recede; first the intense immediacy of the national struggle for independence could no longer be felt; secondly, the limiting nature of nationalism expressed in the form of many protests and failures made its uncritical acceptance impossible. In fact, it became inaccessible to these writers, while, at the same time refusing to be ignored by them. Hence, they had to begin with subverting the generic categories to represent the fragmentary, meandering and unwinding mechanisms of postcolonial societies. They started treating "the authoritative orthodoxy of India in a plural fashion, turning accepted 'truths' into "a new set of unverifiable facts" (Sethi 965). Maintaining a close relationship with indigenous models of 
history, autobiography and other related forms their writings produced a 'de-totalizing palimpsest of.... Memory's truth' (Sethi 965). Such process of assembling reality has inevitably coincided with a 'rethinking of the relevance of multiple and shifting social identities' (Bose\& Jalal 243).

\section{Nationalism in Gosh's Fiction}

Amitav Ghosh. inheriting the literary tradition of Bengal which constructs the spirit of nationalism, not in terms of 'intense failure' and 'gory success', but in the simple acts of reaffirmation of Bengali culture, dress and language (Nandy 72) builds up an impressive critique of such stifling categories like the monolithic nationstate. He posits the complex histories of communities across the states and writes the courageous and continuous struggles of nationalities against the rigid boundaries of the state. He deliberately takes most of the South Asia and Egypt for his fictional setting. Cambodian stories in stones, Burmese nationalism with its anti-Indian origins and shades, the Karen nationalist struggles, the trauma of Bengal partition and the corridors of historical connections in Colombo constitute the broad themes of his fiction.

His narratives, constructed with 'the benefit of hindsight', try to 'recover some of the emotions which were felt and experienced' (see Jones 1988) during 'those terrible times(s)' of communal riots, displacement, migration, partition, and other such traumatic events of the postcolonial societies. Ghosh feels that these events must be captured in the local forms and details. A narrative, he strongly feels, can capture the 'moment' only when it recovers the felt echoes and impact of an event. While analyzing the fundamentalist threat to the Egyptian novelist Naguib Mahfouz, he highlights this particular aspect in 'The Writer and the Holy Script'-'Our point of entry into even the largest of events is inevitably local, situated in and focused on details and particulars.' An experience or an event is realized with all its subjective dimensions in such a localized recapitulation. The possibility of the reader getting involved in the narrative and supplying it a 'broader context' and populating 'the scene with products of his or her experience and learning' (ibid) is also ensured.

\section{Memory, a Narrative Technique in Gosh's The Shadow Lines}

Memory, a crucial device in the narrative, operates through more than one narrator, thus forming layers on it. Usually, the protagonist recounts his experience of events, of people only to be corroborated by the accounts of the same events by the people remembered. An event often is recalled more than once, in the fictional text. The truth of the event so recalled can possibly be interrogated by the reader. Or more suggestively, the reader is reminded of the possibility of many more such 'recalls'. For him to weave a thread of meaning, a broad context has to be inserted into the maze of recalls. So several recalls only allow an event or an occurrence to reclaim its own fluidity. And Ghosh certainly believes in attaching such uncertain, ambiguous fluidity to events and lives. Elaborating the idea of writing in The Circle of Reason, he says: 'I used to live in a village... I found there was a lot of movement in people's lives. I wanted to write about this strange kind of fluidity' (12). The narrative, trying to capture such fluidity, becomes necessarily loose, meandering and inclusive.

The Shadow Lines, the second novel in Ghosh's oeuvre, is growing up remembered. The circumstances of this growing up are filled with the 'weight of remembered details', which draw the shadow lines of identity and nationalism. These lines or marks of identity are mainly drawn around two characters, the narrator and his cousin Ila who are of the same age, but brought up in two different worlds which keep intersecting each other. Probably this intersected space of these worlds is the constituted space for the posited identity. The narrator grows in Calcutta with his grandmother and other relatives coming to his household, and consequently into his world, with the long shadow of Tridib, uncle, Archaeologist and well-cast Adda-leader (Adda means gossiping). Ila, on the other hand, is the daughter of an uncle who is a U.N. Official and consequently keeps shuttling internationally from country to country and city to city, only to come regularly to Calcutta for Durga puja (a major Hindu religious festival). The narrator, who grows up on stories of various worlds narrated to him by his grandmother, Tridib and his school, keeps his learning to use his 'imagination with precision'. He keeps inventing these places, locating them on Tridib's 'tattered old Atlas' and filling them with the stories told by Tridib and the souvenirs Ila used to bring from various cities in the world. So, for the narrator, a place is invented before it exists. He says, 'a place does not merely exist, that it has to be invented in one's imagination' (21). Ila could not understand this; for her Cairo or Colombo are as good as the schools in those cities she attended with the boys and girls she met. Though she has moved from place to place, 'she had never travelled at all'. Ila cannot imagine a place beyond the experience of her school nor 'travel' even when she moves so frenetically all over the world because she lives 'so intensely in the present'. It is a 'present which was like an airlock in a canal, shut away from the tidewaters of the past and the future by steel flood gates" (30). This intense life in the present, characterized by flight, makes her unable to relate to anything, not even to her English boyfriend, 'Nick Price' who 'was ashamed to be seen by his friends, walking home with an Indian.'(36).

This life in the present alienates her progressively. Her plight is well captured in the image of her 'walking alone in a drizzle under that cold gray sky' ... 'through the lanes of West Hampstead'. The narrator cannot imagine the same Ila walking alone in Calcutta with 'all of us. I, her relatives, her friends, all waiting to walk (for)... Ila 
the sophisticate (76). 'The protagonist-narrator, on the other hand, grows in the settled ambience of a Calcutta household with his grandmother. Tridib gives him 'worlds to travel in' and 'eyes to see them' before he really starts seeing them and seeing them for what they are. Past, which was not available to Ila, is made available in the form of recollections, explanations and experiences of the people around him, particularly through his grandmother armed with an accessible past he imagines 'with precision'. The world for him originates in the past, grows in the happenings of the present and becomes 'known' in the realization of desire. He recollects the words of Tridib:

He said to me once one could never know anything except through desire; real desire.... a pure, painful land primitive desire, a longing for everything that was not in oneself.... That carried one beyond the

limits of one's mind to other times and other places.... (29)

'Primitive desire' to reach beyond himself connects his past to his future the course of which is already charted out in his ambition fuelled by the archaeological experiences of various places by Tridib, the metropolitan lives of the Princes and the international movement of Ila. The receding shadow of his grandmother and the felt need for the alluring Ila only signify his preparedness to embrace other worlds.

His descriptions of rich details in and around Calcutta only show the narrative emphasis on the travel motif. He would see 'the floating talkative population' 'gravitated towards that conversation-loving stretch of road-between Gariahat and Gole Park" (The Shadow Lines, 8). The traffic near Dakshineswar and the vast crowds circulating in the courtyard of the temple below, like 'floodwaters sweeping through a garden' the image of 'speeding along the Grand Trunk Road', all give 'a tired intimacy' to the narrator and prepares him to travel in and across cultures. His notions are juxtaposed to those whizzing movements of Ila.

The narrator gathers experiences of various places and cultures, which help him, reach beyond him. Such gathering of experiences can only happen after the colonial relationship of authority concedes considerable ground for the emerging social formations. However, these social formations are as altered as the identities they throw up. In other words, they can only be inclusive and composite.

The characters around the narrator and Ila, bring in themes of their own. The grandmother contrasts sharply with the transitional world of Tridib and the composite world of the narrator. She embodies the life of experiencing two tragic developments. Despite diligent efforts to keep her old world unaffected, intrusions do take place. The alien world of the British rule and the consequences it engenders impinge and make 'impure her world of ancient stable values'. Secondly, she grows up in Dhaka and settles in Calcutta without any feeling of being uprooted. Then, she, who used to board the train in Dhaka in the evening and reach Calcutta the following morning, is told that these two places have become parts of two countries. She cannot understand how such a thing as partition of her country could take place. It does not make any sense to her. She wonders: 'Where is the difference then? And if there is no difference both sides will be the same; it will be just like it used to be before' (151).For her somebody belongs to a nation or a nation belongs to her only when she inherits a life in it: that is, her forefathers must have shed their blood for the nation or at least died there. Mere living in a country does not make it one's own. She expresses as much when she tells:

It took those people (The English) a long time to build that country: hundreds of years, years and years of war and bloodshed. Everyone who lives there has earned his right to be there with blood.... They

know they're a nation because they have drawn their borders with blood. (78)

Dhaka, for her, was such a place; her forefathers lived there; she has spent her childhood and adult years there and, hence, inherited and lived that place. So she cannot accept the partition of such a place nor understand it in any possible way. By the same logic her country, India, cannot be ruled by the British; they simply do not belong to his place. What is rightfully hers through thousand years of lived association cannot be theirs by annexation. Again by the same logic she asks Ila to come back to India. She can never be part of West Hampstead of England for that country is insulated by thousand years of history. Hence she would only be lonely and unhappy there. For her a country is not just a territorial unit, but an entity filled with memories, sacrifices and achievements. Its institutions are 'lined with memorial to men', (34) who contributed to its history.

In contrast, there are Himangshusekhar Datta-Chaudhuri, 'the Saheb' and Alan Tresawsen. The Saheb is so Europeanized that 'his hat wouldn't come off his head' (63). He wears his clothes of 'Indian diplomat, English gentleman' and South club tennis player not so much for necessity but for 'putting them on parade'. When he, with a tweed jacket and stripped tie, says he is an Indian. Mike asks him, "... killed any Englishman yet? The Saheb retreated a step in horror' (20). Despite all his roles, he does not know what makes him an Indian. Nor does anybody including his friends understand his Indianness. Tresawsen, on the other hand, while making a living in India, earns the trust and friendship of a number of nationalists and comes closer to The Theosophical Society. For him an Indian expresses his nationality in continued opposition to the British rule. $\mathrm{He}$, symbolically, leaves India for a settled life in England. These two characters not only qualify the nationalist spirit embodied in the character of the grandmother but represent other shades to it. The narrator, nurtured by such a staunch nationalist, grows up to include other available shades of the same spirit in his notions of 
Indianness, thus signifying the spirit of Indian nationalism beyond the categories constructed in opposition to the colonial rule.

\section{Conclusion}

Amitav Ghosh, by bringing these characters of different generations to speak of their notions of what constitutes a nation would only suggest the need for evolution of the categories much beyond their origins in the colonial regime. Rigidities, brought about by the attendant details of the colonial rule, need to be softened by an awareness of the deeper needs and histories of, the communities inhabiting, sometimes across, these rigid structures, an awareness which might not have surfaced or shown signs of surfacing earlier, say for instance, about fifty years ago and which, in any case was not accessible to alien attempts.

[1]. Nandy, The illegitimacy of nationalism (Delhi: OUP, 1994)

[2]. R. Sethi, The writer's truth: representation of identities in Indian fiction, Modern Asian Studies, 31(4), 1997. 965.

[3]. S. Bose, and A. Jalal. Modern south Asia (Delhi: OUP, 1998).

[4]. W. Jones, Gentle Iconoclast, The New Indian Express, 1988 n.d.

[5]. A. Ghosh, The writer and the holy script, The Telegraph. 27 August 1995

[6]. A. Ghosh. The Shadow Lines (Delhi: Ravi Dayal Publishers, 1988). 